\title{
Proposing Blue Sukuk in Indonesia: An Interpretive Structural Model
}

\author{
Aam Slamet Rusydiana ${ }^{a}$, Mohammad Iqbal Irfany ${ }^{b}$ \\ a Sharia Economic Applied Research \& Training (SMART), Indonesia \\ ${ }^{b}$ Faculty of Economics and Management, IPB University, Indonesia \\ Corresponding email: aamsmart@gmail.com \\ do) http://dx.doi.org/10.22515/shirkah.v6i1.333
}

\begin{tabular}{|c|c|}
\hline ARTICLE INFO & ABSTRACT \\
\hline $\begin{array}{l}\text { Keywords: } \\
\text { Blue Sukuk; Interpretive } \\
\text { Structural Model; Sovereign } \\
\text { Sukuk } \\
\text { Article history: } \\
\text { Received: } 31 \text { August } 2020 \\
\text { Revised: } 14 \text { December } 2020 \\
\text { Accepted: 06 February } 2021 \\
\text { Available online: } 15 \text { April } 2021 \\
\text { To cite in APA style: } \\
\text { Rusydiana, A. S., \& Irfany, M. I. } \\
\text { (2021). Proposing Blue Sukuk in } \\
\text { Indonesia: An Interpretive } \\
\text { Structural Model. Shirkah: } \\
\text { Journal of Economics and Business, } \\
\text { 6(1), 101-114. }\end{array}$ & $\begin{array}{l}\text { This research aims to identify the priority factors that being } \\
\text { barriers to issue and develop Islamic blue sukuk in Indonesia. } \\
\text { Employing the Interpretive Structural Modeling (ISM) method, } \\
\text { it also offers several solutions for the identified problems. As } \\
\text { an advanced planning methodology, ISM is used to identify, } \\
\text { analyze, and summarize various relationships among factors } \\
\text { that define a problem, model, or issue. In the ISM framework, } \\
\text { there are three criteria of blue sukuk development in Indonesia } \\
\text { including (1) aspect or foundation required within the } \\
\text { framework of developing blue sukuk; (2) infrastructure that } \\
\text { will be used as a basis for sukuk issuance (underlying projects); } \\
\text { and (3) stakeholders involved in the development of blue } \\
\text { sukuk in Indonesia. Results show that important foundations } \\
\text { needed in the development of blue sukuk are regulatory } \\
\text { aspects, feasible underlying projects, investors, and inter- } \\
\text { institutional coordination, respectively. Finally, possible } \\
\text { underlying infrastructures for the issuance of Blue Sukuk are } \\
\text { the development of integrated fishing villages as well as the } \\
\text { procurement of large and environmentally friendly fishing } \\
\text { boats. }\end{array}$ \\
\hline
\end{tabular}

This work is licensed under a Creative Commons Attribution-NonCommercial 4.0 International License.

\section{Introduction}

Indonesia is the second largest sukuk issuing country in the world during the first semester of 2019. With an issuance value of US \$ 15 billion or Rp214 trillion, the government takes up 18 percent of the total world sukuk issuance of US \$ 87 billion or equivalent to Rp1,244 trillion (Moody's Investors Service, 2019). Indonesia only lost to Malaysia in terms of sukuk issuance. One of the reasons for the large issuance of Indonesian sukuk is the issuance of green sukuk. Indonesia will expand the use of green sukuk in line with Indonesia's commitment to reduce carbon emission levels and build projects that are more environmentally friendly. Another alternative in this type is the blue sukuk. 
The maritime sector has complicated problems as its association with many sectors and sensitive to interactions especially related with environmental aspects. There are various issues in marine fisheries management in Indonesia that potentially threaten the preservation of fish resources and the environment, the sustainability of community livelihoods in the field of fisheries, food security, and economic growth. (Ministry of Maritime Affairs and Fisheries, 2019).

Marine economics, or widely known as Blue Economy, is the concept of optimizing water resources that aims to increase economic growth through various innovative and creative activities while ensuring business sustainability as well as environmental sustainability (Ilma, 2017). It is important to note that this concept emphasizes efficiency that encourages the development of investment and fisheries business while maintaining a sustainable environment. Efficiency means, there is a proportional ratio between input and output in economic growth. In addition, the expected output does not contradict the current SDGs concept.

The main core of Blue Economy is basically pro-ecosystem activities. Rani and Cahayasari (2015) argue that the marine economy is still a relatively lagging sector when viewed from the low productivity of the level of resource utilization, technology used, poverty, and environmentally friendly activities. In addition, the interest of medium and large-scale investment to this sector is relatively less given a large amount of capital needed even though the rate of return is relatively high. Hence, optimization of the marine economy, both for community welfare, energy security, and future food sources, requires various scheme of financial supports. In this regard, the government needs to develop a financing instrument that can be used to develop a blue economy in Indonesia. One step that can be taken is by inviting investors through instruments provided by the government such as the State Sukuk (Islamic bond).

One of prospective financing instruments issued by the government is Green Sukuk. The issuance of this sukuk type is almost the same as other State Sukuk. The current State Sukuk is mostly used to finance infrastructure. The only difference is that the infrastructure that will be used as a basis for issuance (underlying assets) must meet the criteria of green infrastructure. In this regards, infrastructure from the agricultural sector such as the wind energy sector (Morea \& Poggi, 2017), the construction of reservoirs, irrigation and hydropower is very potential to be categorized as a green infrastructure as it supports the use of water to be more efficient (sustainable water management), reduces the use of ground water for agriculture, and increases the use of non-fossil renewable energy (Handayani \& Surachman, 2017; Anggraini, 2018). The concept of Blue Sukuk is not much different from Green Sukuk. The difference is that Blue Sukuk is more focused on financing the marine economy.

Several previous studies related to the development of sukuk and blue economy have been conducted. For instance, Ismatullah (2011) in his research entitled "Maritime Economic Paradigm in the Perspective of Islamic Economics", explains that the pattern of Indonesia's economic development in the future must be oriented towards marine economic policy. In this context, his study finds that from the very beginning the Qur'an has highlighted the problems of the marine economy intensely in its verses. 
Other studies related to sukuk especially the theme of state-owned sukuk in several regions have been conducted by Arshad et al. (2018), Mitsaliyandito and Arundina (2018), Rahman et al. (2017), Altaleb and Alkhatib (2016) and Nienhaus and Karatas (2016). Specific research takes the area of study in Indonesia, for example, conducted by Mitsaliyandito and Arundina (2018) and Jarkasih and Rusydiana (2009). Mitsaliyandito and Arundina (2018) try to measure the impact of the development of the government bond and sukuk market as one of Indonesia's financing instruments on economic growth, and vice versa. Meanwhile Jarkasih and Rusydiana (2009) saw the development of the sukuk market in Indonesia and compared with developments in neighboring Malaysia and in general in the world.

The principle of Islamic finance, including sukuk can be widely applied in an economic system which does not only focus on the profit sharing system, but also impeccably instills ethical codes (moral, social, and religious) in promoting fairness and welfare to the wide community. There are no different principles among the Islamic financial institutions as these institutions generally emphasize on the partnership relation (mutual investor relationship) with profit sharing scheme as its fundamental basis.

More recent research related to green sukuk was carried out by Abdullah and Nayan (2020). The results of this study show that there are several suitable contracts for green sukuk issuance. As well as being aware of the project categories available for green sukuk issuance. The results of this study can also provide confidence and boost investors' confidence in green sukuk. Through the information generated, it is hoped that this will enhance the wider participation in the green sukuk market.

Research related to the development of the blue sukuk has never been carried out because of its relatively new concept. Related research is Anggraini (2018) and Morea \& Poggi (2017) which examines green sukuk in Italy. In response to this issue, the present research aims to look at and identify the factors that potentially hinder the development of blue sukuk in Indonesia. Qualitative modeling in the form of Interpretive Structural Model or ISM is used.

This study tries to answer the following questions. First, what are the problem aspects faced in the issuance and development of Islamic blue sukuk in Indonesia? Second, what are necessary and crucial strategies or foundations in blue sukuk development in Indonesia? Lastly, what are key stakeholders (ecosystem) involved in the development of blue sukuk in Indonesia? This study has potentially fills the gap on what and how the possibility of the issuance of Blue Sukuk to diversify innovative sharia-compliant financing scheme(s) in the maritime sector in Indonesia.

\section{Method}

Interpretive Structural Modeling (ISM) is an advanced planning methodology used to identify, analyze, and summarize various relationship among factors that define a problem, model, or issue (Sage, 1977). ISM is a tool that allows researchers to impose an order and create models around factors of a system by developing the complexity of relationships among them (Warfield, 1974). The method is 'interpretive' in the sense 
that the expert decisions develop the relationships among the variables. It is also 'structural' on the basis of proposed relationships that create an overall structure extracted from a complex set of factors. Finally, it is a 'modeling' technique as the specific relationship and overall structure are portrayed carefully in a graphical model as well as words (Li \& Yang, 2014). As a modeling technique, ISM has been extensively used in different domains to understand the relationship among the various factors that contribute to a whole system (Faisal \& Al-Esmael, 2014). ISM analysis and modeling can help managers and practitioners visualize issues through a systems approach. It can then identify factors that have high levels of influence and therefore require significant attention and effort to resolve the issues (Jabeen \& Faisal, 2018).

ISM is a decision making method took from the complexity situation by correlating and organizing the idea into the visual map. The ISM basic concept allows experts and practitioners to generate complex system into some sub system (element) and build a hierarchy structural modeling. It is also used to give the basic understanding from the complexity situation, and arranging the strategy to solve the problems (Gorvett \& Liu, 2007).

Table 1. Interconnection between Sub-element in ISM

\begin{tabular}{lll}
\hline No. & Type & Interpretation \\
\hline 1. & Comparative & . A more important than B \\
& & . A is attribute of B \\
2. & Definitive & . A including inside B \\
& . A interpret B \\
& & . A cause B \\
& . A develop B \\
3. & Influence & . A improve B \\
& & . A is south/north B \\
& & . A above B \\
4. & Spiral & . A to the left B \\
& & . A precedes B \\
& & . A follow B \\
5. & Temporate/Time Scale & A have more priority then B \\
\hline
\end{tabular}

There are several stages to employ ISM method in our analysis. The first stage is problem decomposition. In this stage, experts or practitioners (who has better understanding on blue sukuk issuance problem) identify and brainstorm the ideas of the organization development of sukuk issuance. From this discussion, the development strategies and variables used in ISM will be explored. The second stage is constructing Structural Self Interaction Matrix (SSIM). This matrix is constructed from the variables founded from decomposition step. Also, we then develop the contextual relationship among variables and gathering into one variable $i$ and variable $j$. The third 
stage is creating reachability matrix (RM) by conversing the $\mathrm{V}, \mathrm{A}, \mathrm{X}$, and $\mathrm{O}$ used into the numbers 1 and 0 . The fourth stage is creating canonical matrix to identify the level through the iteration. If the intersection is no longer found, the next step is creating the model resulted from the ISM software. The resulted model is then used to solve the problem (in this study: blue sukuk issuance and development model). In addition, we can also explored the road map of organization development (level) from the model.

The process of ISM method is calculated according to the Transivity Rule where the correction of SSIM is done until a closed matrix occurs (Marimin, 2004). SSIM modifications require input from panelists or experts, with special notes for attention shown only on certain sub-elements. The revised results of the SSIM and the matrix eligible for the Transivity Rules are further processed. For revision can also be done transformation matrix with computer program.

There were several studies on Islamic economics and finance that have been conducted by employing the ISM method. For instance, a study conducted by Rusydiana and Devi (2018) on sharia cooperatives, Ascarya et al. (2012) on development of shariah banks, and Devi and Rusydiana (2016) on group lending model, among others, also Khairunisa et al. (2017) and Rusydiana (2018a, 2018b). Meanwhile Sharma et al. (2017), Mazdeh et al. (2015), Kazemi (2015), Bolanos et al. (2005), and Kanungo \& Batnagar (2002) employ the ISM method for other industrial applications. On more theoretical aspects, various studies employed the ISM method have been conducted by Lee (2007), Takkar et al, (2007), among others.

\section{Results}

Based on the problem identification of blue sukuk issuance in Indonesia, an ISM network structure was developed. To develop the contextual relationship among the factors, the ISM method suggests the use of experts' opinions. For this research, a group of experts was formed by contacting a number of academicians and practitioners. To develop the initial model, we decided to follow the traditional method of conducting a brainstorming and in-depth interview, as we received inputs of the expert and revise simultaneously. A summarized literature review on blue sukuk development was communicated to the experts. The total number of informants is 30 respondents, consisting of regulators (7\%), practitioners (13\%), association representatives $(17 \%)$, and sharia experts on Islamic capital market (13\%). The rest are academics or researchers (50\%). From all informants, 67\% had doctoral education background and 33\% were master's degree.

To analyze the relationships among the enablers of blue sukuk development, a contextual relationship of 'leads to' type was chosen, meaning that one enabler led to another. From this basis, the contextual relationships between the factors were 
developed. Experts were interviewed in questionnaire to compare the column statement with the row statement for each cell, and to choose a value from the set $(\mathrm{V}$, $\mathrm{A}, \mathrm{X}$ and $\mathrm{O}$ ) representing their perception of direct relationship between two sources at each time.

\section{Structural Self-Interaction Matrix (SSIM)}

The 7 (seven) variables were put in a row and column format (in Indonesia blue sukuk strategies). Variables in rows and columns are represented by $i$ and $j$, respectively. Thus, each pair of variables is analyzed separately after the formation of grid, which was obtained in the above process. Four keywords are used to represent the direction of the relationship between a set of the variables ( $i$ and $j$ ), as follows: $V$ indicates that variable $i$ helps to achieve variable $j$; $A$ indicates that variable $j$ helps to achieve variable $i ; X$ indicates that variable $i$ will help to achieve variable $j$ and variable $j$ will help to achieve variable $i$, or causality relationship; and $O$ indicates that variable $i$ and $j$ are unrelated.

The relationships between variables are presented in a matrix, known as structural self-interaction matrix (SSIM), with the value for each pair of variable was agreed among experts.

Table 2. Structural Self Interaction Matrix (SSIM)

\begin{tabular}{lllllllll}
\hline No & Variable description & $\mathbf{7}$ & $\mathbf{6}$ & $\mathbf{5}$ & $\mathbf{4}$ & $\mathbf{3}$ & $\mathbf{2}$ & $\mathbf{1}$ \\
\hline A1 & Shariah compliance & $\mathrm{A}$ & $\mathrm{O}$ & $\mathrm{X}$ & $\mathrm{V}$ & $\mathrm{A}$ & $\mathrm{A}$ & \\
A2 & Regulation & $\mathrm{V}$ & $\mathrm{A}$ & $\mathrm{V}$ & $\mathrm{V}$ & $\mathrm{A}$ & & \\
A3 & Underlying asset & $\mathrm{X}$ & $\mathrm{X}$ & $\mathrm{V}$ & $\mathrm{V}$ & & & \\
A4 & Technical/operational & $\mathrm{A}$ & $\mathrm{A}$ & $\mathrm{A}$ & & & & \\
A5 & Human resource & $\mathrm{A}$ & $\mathrm{O}$ & & & & \\
A6 & Investor & $\mathrm{X}$ & & & & & & \\
A7 & Institutional coordination & & & & & & & \\
\hline
\end{tabular}

Notes: Entry in the cell: $\mathrm{V}$ when row influences the column; A when column influences the row; $\mathrm{X}$ when row \& column influences each other; and $\mathrm{O}$ when there is no relation between row \& column.

\section{Reachibility Matrix}

The reachibility matrix is obtained from SSIM by conducting a two-step process. In the first step, the alphabets used to indicate the relationships among the variables in SSIM are replaced by " 0 " or " 1 ". The value in the reachibility matrix depends on the type of relationship in the SSIM (Faisal, 2015). If the relationship between a variable in a row with another variable in a column is " $\mathrm{V}$ ", then in the initial reachibility matrix, the row entry becomes " 1 " while the column entry between these two variables becomes " 0 "; If the relationship between a variable in a row with another variable in a column is " $\mathrm{A}$ ", then in the initial reachibility matrix, the row entry becomes " 0 " while the column entry 
between these two variables becomes " 1 ".

Meanwhile, if the relationship between a variable in a row with another variable in a column is " $X$ ", then in the initial reachibility matrix, the row entry becomes " 1 " while the column entry between these two variables becomes " 1 ". Lastly, if the relationship between a variable in a row with another variable in a column is " $\mathrm{O}$ ", then in the initial reachibility matrix, the row entry becomes " 0 " while the column entry between these two variables becomes " 0 ".

Based on the above rules, the initial reachibility matrix for the enablers to blue sukuk development is then constructed. Next, by incorporating transitivities the final reachibility matrix is obtained (Ravi, 2015). The transitivity of the contextual relation is a basic assumption in the ISM. It assumes that if variable $X$ relates to $Y$ and $Y$ relates to $Z$, then $X$ necessarily relates to $Z$ (Venkatesh et al., 2015; Jabeen et al., 2017). The reachibility matrix also provides the driving power and dependence power of each enabler. Thus, in the table of final reachibility matrix, the driving power for A1 (Shariah compliance) is the total sum of the values of the entries in the row, which is 3 . The dependence (the sum of the entries in the column) is 6. Similarly, the values of driving power and dependence are calculated for all the remaining enablers.

Table 3. Final Reachibility Matrix (RM)

\begin{tabular}{|c|c|c|c|c|c|c|c|c|c|}
\hline No & Variable description & 1 & 2 & 3 & 4 & 5 & 6 & 7 & $\begin{array}{l}\text { Driving } \\
\text { power }\end{array}$ \\
\hline A1 & Shariah compliance & 1 & 0 & 0 & 1 & 1 & 0 & 0 & 3 \\
\hline A2 & Regulation & 1 & 1 & 1 & 1 & 1 & 1 & 1 & 7 \\
\hline A3 & Underlying asset & 1 & 1 & 1 & 1 & 1 & 1 & 1 & 7 \\
\hline A4 & Technical/operational & 0 & 0 & 0 & 1 & 0 & 0 & 0 & 1 \\
\hline A5 & Human resources & 1 & 0 & 0 & 1 & 1 & 0 & 0 & 3 \\
\hline A6 & Investor & 1 & 1 & 1 & 1 & 1 & 1 & 1 & 7 \\
\hline \multirow[t]{2}{*}{ A7 } & Institutional coordination & 1 & 1 & 1 & 1 & 1 & 1 & 1 & 7 \\
\hline & Dependence Power & 6 & 4 & 4 & 7 & 6 & 4 & 4 & \\
\hline
\end{tabular}

After calculating the final reachibility matrix, the next step is to establish reachibility and antecedent sets. The reachibility set for a particular enabler consists of the enabler itself and other enablers that may help to achieve. Similarly, the antecedent set consists of the enabler itself and the other enablers that influence it. The intersection of these sets is derived for all the enablers. The enablers for which the intersection and reachibility set are the same form the top level of the hierarchy in the ISM model. These enablers would not help achieve any other enabler above their level (Jabeen \& Faisal, 2018). The identified levels help in building the diagraph and the final model of ISM.

\section{MICMAC Quadrant Analysis}

On his study, Godet (1986) has popularized the matrix of cross impact multiplications applied to classification (MICMAC) analysis to classify the system 
variables under study. The basis of this classification is the driving power and dependence that is calculated in the final reachibility matrix. Additionally, the MICMAC analysis may be used in examining direct and latent relationships among enablers obtained from the ISM technique. Thus, based on the driving power and dependence, enablers in our present study are classified into four clusters.

The first cluster is autonomous variables. These variables have neither high driving power nor high dependence. They are detached from the system, with which they have few links that may be very strong. Quadrant I represents autonomous variables. In our study, none of the variables fall into this category. The second cluster is dependent variables. Quadrant II represents dependent variables that have low driving power and high dependence. From the MICMAC analysis, Enabler 1, 4 and 5 are considered as dependent variables, i.e. shariah compliance, human resource and technical.

Furthermore, the third cluster is linkage variables. These variables have high driving power and high dependence. Their characteristic is that any action on them will have an effect on the variables above their level and a feedback effect on themselves. Quadrant III represents linkage variables. In our study, Enabler 2, 3, 6 and 7 can be considered as linkage variables, including regulation aspect, underlying asset, investor and institutional coordination. The forth cluster is independent variables. These variables have high driving power and low dependence. They represent Quadrant IV. In our study, none of the variables fall into this category.

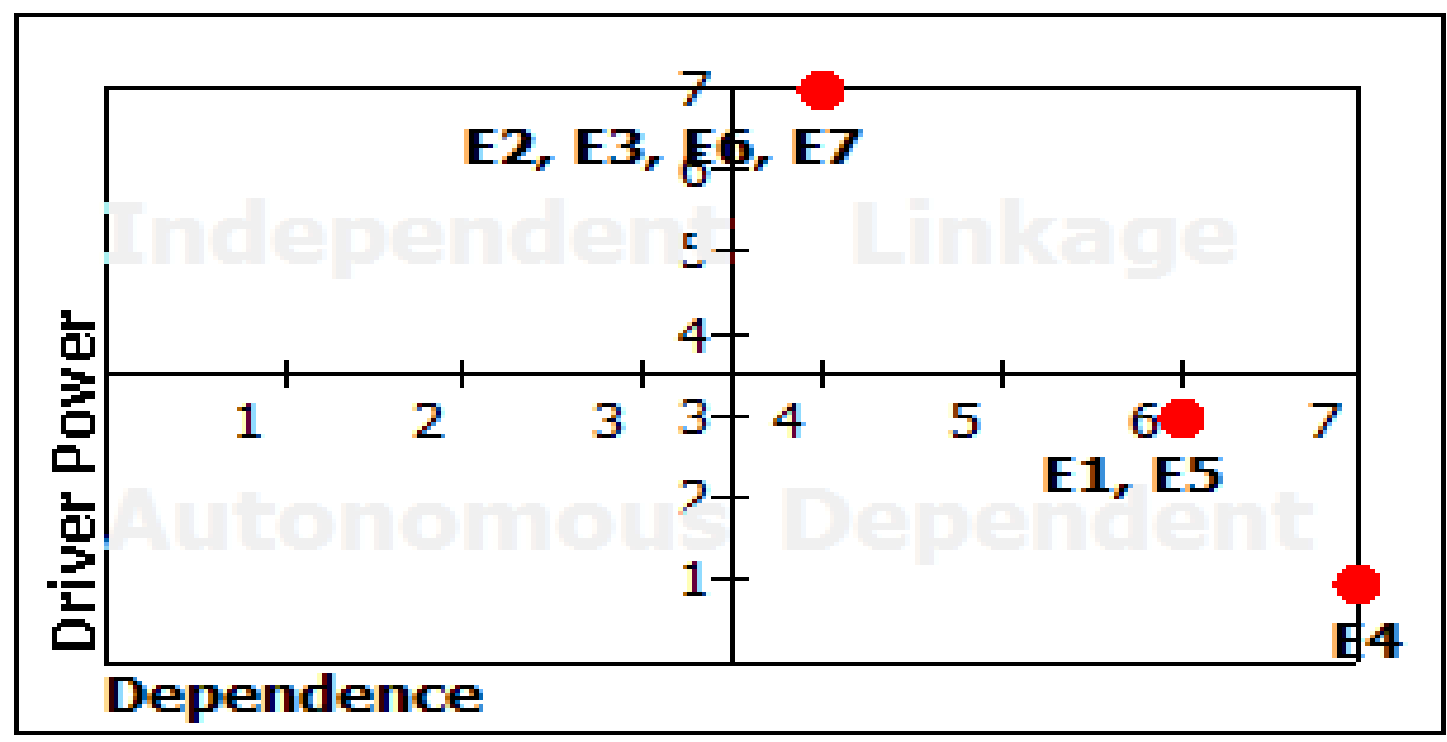

Figure 1. MICMAC Analysis of Blue Sukuk Aspects

\section{Discussion}

From the aspect of strategy or foundation that is needed in framework of blue sukuk development, especially in Indonesia, the core foundation are Regulation, Underlying asset, Investor and Institutional coordination (Level 3). The next foundation are 
Shariah compliance and Technical/operational aspect (Level 2). The last but not least is Human resource (Level 1).

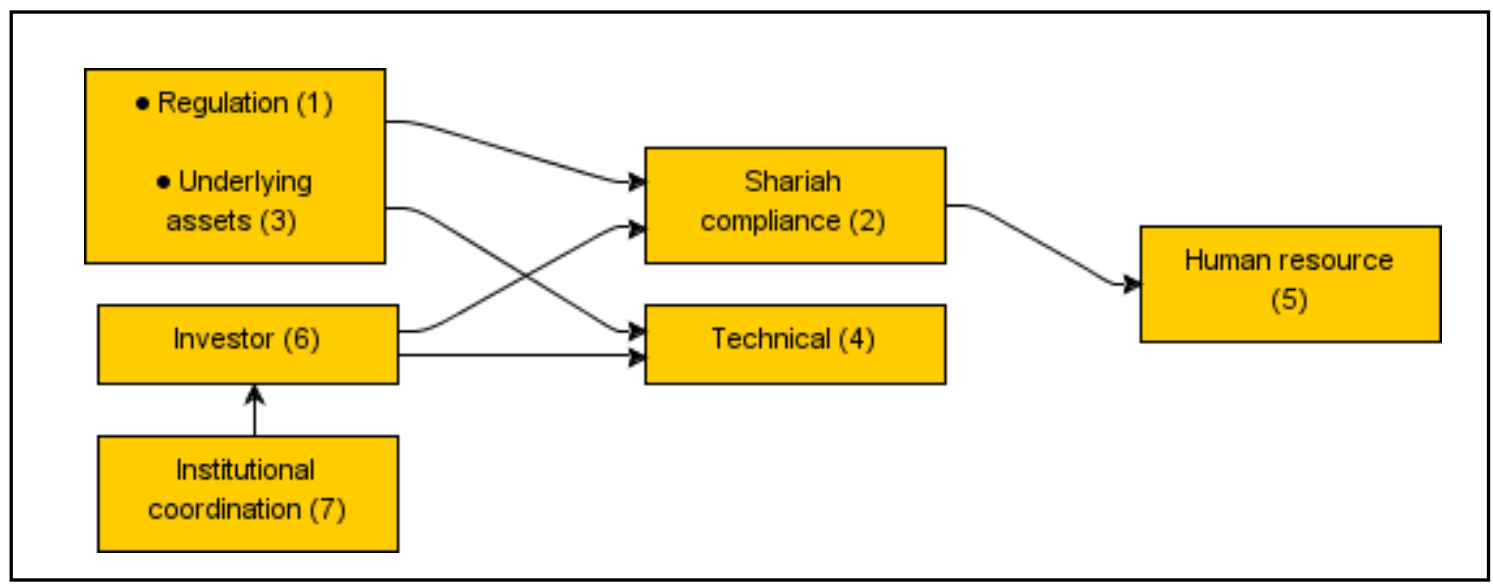

Figure 2. Level of Important Aspect in Blue Sukuk Issuance

This research found that the most important aspect in the issuance of blue sukuk in Indonesia is regulation. Previous studies conducted by Jarkasih and Rusydiana (2010) as well as Altaleb and Alkhatib (2016), also found that regulation is an important aspect in the issuance and development of sukuk. While Jarkasih and Rusydiana (2010) conducted the case of corporate sukuk in Indonesia, Altaleb and Alkhatib (2016) conducted the case study of the sovereign sukuk in Jordan.

The second most important aspect is related to underlying assets. This aspect is also crucial because once blue sukuk has been issued, it needs real projects that are feasible to be financed. The underlying assets, for instance, can be in the form of dock infrastructure financing, or procurement of fishing boats (Kadir et al., 2016). Based on in-depth interviews with experts from the Ministry of Finance, the underlying projects can also be in the form of an integrated fishing village development. This can even support "the sea toll infrastructure" that has been proclaimed by the government.

Another important aspect is related to investors. Similar to successful story of green sukuk issuance, the issuance of blue sukuk allows all public investors, both domestic and foreign investors (such as from Arab countries, Europe and other countries). Blue sukuk in Indonesia is even possible to be the first and the only blue sukuk in the world, as there have never been similar financing instruments in any country.

Other important aspect that is also important in the development of blue sukuk is inter-agency coordination. There are several government agencies that are concerned in the issuance and development of blue sukuk in Indonesia, for instance the Ministry of Finance (acting as a publisher), the Ministry of Maritime Affairs and Fisheries (in supporting underlying projects), the Ministry of National Development Planning (in conducting initial feasibility study). The Ministry of Public Work and Housing and The 
Ministry of Transportation may also have interests in developing maritime infrastructures (Hariyanto, 2019). In relation to the elements of underlying projects in the issuance of blue sukuk in Indonesia, there would be several options as follows: (1) development of integrated fishing villages, (2) procurement of large fishing vessels, (3) conservation of marine and maritime ecosystems, (4) "sea toll" infrastructure, and (5) construction of docks, and so on.

Regarding the blue sukuk stakeholders in Indonesia, the important actors are as follows: (1) Government or regulator, in this case the Ministry of Finance, then (2) the Ministry of Marine and Fisheries. The next level of stakeholder involved in Islamic blue sukuk in Indonesia are the following: (1) The Ministry of Public Work and Housing, (2) Public investor, (3) Fishing community, and (4) Islamic financial institutions. As we know, the government significantly influences the development of Islamic finance in general, including sukuk. In this case, the regulation that provides support will be expected to help facilitate the development of the Islamic blue sukuk issuance in the future.

The core foundation of blue sukuk development in Indonesia are about regulation, underlying asset, investor and institutional coordination. Regulation is important in the development of financial instruments, especially those related to state financing. Rusydiana (2018b) states that regulation is one of the keys to developing Islamic social finance. Apart from that, from the blue sukuk perspective, other aspects cannot be ruled out, such as: the underlying asset aspect and the investor side. Morea and Poggi (2017) states that investors are another important aspect of using green sukuk instruments.

\section{Conclusion}

Islamic blue sukuk in Indonesia generally have considerable potential to issue and develop in the future. Based on our analysis, the important aspects in the development of blue sukuk are: regulatory aspects, feasible underlying projects, investors, and interinstitutional coordination, respectively. Possible underlying infrastructures as a basis for the issuance of blue sukuk are the development of integrated fishing villages, and the procurement of large and environmentally friendly fishing boats. Stakeholders that have interests in blue sukuk are the government bodies (the Ministry of finance, the Ministry of marine affairs and fisheries, and The Ministry of Public Work and Housing), investors, and fishery communities.

Islamic financial mechanisms and institutions may have important roles in the context of issuance and development of Indonesian blue sukuk in the future. If it goes well, the issuance of blue sukuk, as an innovative Islamic financing instrument, in Indonesia may be the first and only blue sukuk in the world. This study has several limitations, including the need for variation and a greater number of respondents than 
what has been done. In addition, the research method approach needs to be viewed from another perspective. For example, the use of the ANP method developed by Saaty (2004) or a developed ISM model such as TISM (Total ISM). So that the results obtained are more robust and reliable. As suggestion for the future, it is necessary to have expert respondents who are very familiar with the development of blue sukuk in Indonesia, both academic backgrounds, practitioners and also regulators.

\section{Authors' Declaration}

The authors made substantial contributions to the conception and design of the study. The authors took responsibility for data analysis, interpretation and discussion of results. The authors read and approved the final manuscript.

\section{Acknowledgement}

This research was funded with full self-funding.

\section{ORCID}

Aam Slamet Rusydiana (D) https://orcid.org/0000-0002-0624-7042

Mohammad Iqbal Irfany (D) https://orcid.org/0000-0003-3966-4819

\section{References}

Altaleb, G.S., \& Alkhatib, A.Y. (2016). Sovereign Islamic sukuk and the economic development: A case study of Jordan. European Journal of Business and Management, 8(32), 115-118.

Abdullah, N., \& Nayan, M.A. (2020). Green Sukuk: Financing the Future to Sustainable Environment. International Journal of Zakat and Islamic Philanthropy, 2(2), 14-23.

Anggraini, Y. (2018). Peran green sukuk dalam memperkokoh posisi Indonesia di pasar keuangan syariah global. El-Barka: Journal of Islamic Economics and Business, 1(2), 251-268.

Arshad, H., Muda, R., \& Osman, I. (2018). Impact of exchange rate and oil price on the yield of sovereign bond and sukuk: Evidence from Malaysian capital market. Journal of Emerging Economies E Islamic Research, 5(4), 27-41.

Ascarya, W. G., Widodo C., Enny A., \& Ferry S. (2012). Strategi Meningkatkan Preferensi Perbankan Syariah Indonesia Dalam Menggunakan Pembiayaan Bagi- Hasil. Jakarta: Central Banking Education and Studies Department, Bank Indonesia.

Bolaños, R., Fontela, E., Nenclares, A., \& Pastor, P. (2005). Using interpretive structural modelling in strategic decision-making groups. Management Decision, 43(6), 877895.

Devi, A. \& Rusydiana, A. S. (2016). Islamic Group Lending Model (GLM) and Financial Inclusion. International Journal of Islamic Business Ethics, 1(1), 80-94.

Faisal, M.N., \& Al-Esmael, B.A. (2014). Modeling the enablers of organizational commitment. Business Process Management Journal, 20(1), 25-46.

Faisal, M.N. (2015). A study of inhibitors to transparency in red meat supply chains in Gulf cooperation council (GCC) countries. Business Process Management Journal, 
21(6), 1299-1318.

Godet, M. (1986). Introduction to 'la prospective': seven key ideas and one scenario method. Futures, 18(2), 134-157.

Gorvett, R., \& Liu, N. (2007). Using interpretive structural modeling to identify and quantify interactive risks. Orlando-USA: ASTIN Colloquium.

Handayani, D., \& Surachman, E.N. (2017). Sukuk negara as financing strategy for renewable energy infrastructure: Case study of Muara Laboh geothermal power project. International Journal of Energy Economics and Policy, 7(4), 115-125.

Hariyanto, E. (2019). Blue Sukuk in Indonesia. Results of personal indepth-interviews, August $10^{\text {th }}, 2019$, Tazkia University.

Ilma, A. F. N. (2017). Blue Economy: Kesimbangan Perspektif Ekonomi dan Lingkungan. Jurnal Ilmu Ekonomi Dan Pembangunan, 14(1).

Ismatullah, R. (2011). Paradigma ekonomi kelautan dalam perspektif ekonomi Islam: Reinterpretasi Ayat-ayat Kelautan yang Berdimensi Ekonomi. Jurnal Ekonomi Syariah Indonesia, 1(2), 95-110.

Jabeen, F. \& Faisal, M.N. (2018). Imperatives for improving entrepreneurial behavior among females in the UAE: An empirical study and structural model. Gender in Management, 33(3), 234-252. https://doi.org/10.1108/GM-03-2016-0042

Jabeen, F., Faisal, M.N., \& Katsioloudes, M.I. (2017). Entrepreneurial mindset and the role of universities as strategic drivers of entrepreneurship evidence from the UAE. Journal of Small Business and Enterprise Development, 24(1), 136-157.

Jarkasih, M., \& Rusydiana, A.S. (2010). Mengurai masalah pengembangan sukuk korporasi Indonesia dengan pendekatan ANP. Proceedings at International Academic Conference, Shariah Economic Days 2010 FEUI, 3 February 2010.

Jarkasih, M., \& Rusydiana, A.S. (2009). Perkembangan pasar sukuk: Perbandingan Indonesia, Malaysia dan dunia. Antisipasi: Jurnal Bisnis dan Ekonomi, 1(2).

Kadir, H., Rizal, A., \& Laapo, A. (2016). Analisis Tingkat Keberlanjutan Program Kapal Inka Mina (30 gt) di Desa Labuan Bajo Kabupaten Donggala. Jurnal Sains Dan Teknologi Tadulako, 5(3), 54-64.

Kanungo S \& V.V. Batnagar, (2002). Beyond Generic Models for Information System Quality: The Use of Interpretive Structural Modelling (ISM). Journal of System Research and Behavior Science. 19(2), 531-549.

Kazemi, M. (2015). Compiling the strategy plan using a hybrid of BSC-ISM. Management Science Letters, 5(2015), 11-20.

Khairunisa, R., Akbar, N., \& Devi, A. (2017). Exploring strategies to enhance Islamic banking's role to raise cash waqf funds. Iqtishadia: Jurnal Kajian Ekonomi dan Bisnis Islam, 10(2), 1-28.

Lee, D. M. (2007). Structured Decision Making with Interpretive Structural Modelling (ISM). Canada: Sorach Inc.

Li, M., and Yang, J. (2014). Analysis of interrelationships between critical waste factors in office building retrofit projects using interpretive structural modeling. International Journal of Construction Management, 14(1), 15-27.

Marimin. (2004). Pengambilan Keputusan Kreteria Majemuk. Teknik dan Aplikasi. Jakarta: 
Gramedia Widiasarana Indonesia.

Mazdeh, M.M., Shafia, M.A., Bandarian, R., \& Kahrizi, A. (2015). An ISM approach for analyzing the factors in technology transfer. Decision Science Letters, 4(2015), 335348.

Ministry of Maritime Affairs and Fisheries. (2019). Permen KP Nomor 63 Tahun 2017 tentang : Rencana Strategis Kementerian kelautan Tahun 2015 - 2019.

Mitsaliyandito, R.Q., \& Arundina, T. (2018). Dynamic relationship between sovereign bond and sukuk market developments in Indonesia. Pertanika Journal of Social Sciences E Humanities, 26(5), 27-38.

Moody's Investors Service. (2019). Moody's Annual Report. New York.

Morea, D., \& Poggi, L.A. (2017). An innovative model for the sustainability of investments in the wind energy sector: The use of green sukuk in an Italian case study. International Journal of Energy Economics and Policy, 7(2), 53-60.

Nienhaus, V., \& Karatas, A. (2016). Market perceptions of liquid sovereign sukuk: A new asset class? International Journal of Islamic and Middle Eastern Finance and Management, 9(1), 87-108. https://doi.org/10.1108/IMEFM-03-2015-0027

Rahman, M.P., Duasa, J., Kassim, S., \& Zainudin, W.R.A. (2017). Sovereign sukuk pricing analysis: Do macroeconomic variables matter? International Journal of Economics, Management and Accounting, 25(3), 513-528.

Rani, F., \& Cahayasari, W. (2015). Model Blue Economy di Kawasan Asia Pasifik (Studi Kasus: Penerapan Model Blue Economy pada Industri Perikanan Indonesia). Jurnal Online Mahasiswa Fakultas Ilmu Sosial Dan Ilmu Politik Universitas Riau, 2(1).

Ravi, V. (2015). Analysis of interactions among barriers of eco-efficiency in electronics packaging industry. Journal of Cleaner Production, 10(1), 16-25.

Rusydiana, A.S., \& Devi, A. (2018). Mengembangkan koperasi syariah di Indonesia: Pendekatan interpretive structural model (ISM). Economica: Jurnal Ekonomi Islam, 9(1), 1-23.

Rusydiana, A.S. (2018a). Developing Islamic financial technology in Indonesia. Hasanuddin Economics and Business Review, 2(2), 143-152.

Rusydiana, A.S. (2018b). Analysis of cash waqf development in Indonesia using interpretive structural modeling (ISM). Journal of Islamic Economics Lariba, 4(1), 124.

Saaty, T. L. (2004). Decision making - the analytic hierarchy and network processes (AHP/ANP). Journal of systems science and systems engineering, 13(1), 1-35.

Sage, A. (1977). Interpretive Structural Modeling: Methodology for Large-Scale Systems, McGraw-Hill, New York, NY.

Sharma, V., Grover, S., \& Sharma, S.K. (2017). Analyzing the barriers affecting the effective utilization of quality tools and techniques using integrated ISM approach. Management Science Letters, 7(2017), 525-540.

Thakkar, J., Deshmukh, S. G., Gupta, A. D., \& Shankar, R. (2007). Development of a balanced scorecard: an integrated approach of interpretive structural modeling (ISM) and analytic network process (ANP). International Journal of Productivity and Performance Management, 56(1), 25-59. 
Venkatesh, V.G., Rathi, S., \& Patwa, S. (2015). Analysis on supply chain risks in Indian apparel retail chains and proposal of risk prioritization model using interpretive structural modeling. Journal of Retailing and Consumer Services, 26, 153-167.

Warfield, J. N. (1974). Developing interconnected matrices in structural modeling. IEEE Transactions on System, Man and Cybernetics, 4(1), 81-87. 